\title{
Being Female Affects Business Loans from Family and Friends
}

\author{
Kimberly Eddleston (Northeastern University)
}

KEYWORDS: Entrepreneurship, Finance, Family Business, Women, family relationships.

Building on research that shows that women and men entrepreneurs are rewarded differently by banks for the display of personal commitment to their business and business success, this study investigates if women are also held to a higher standard by family and close friends when seeking financing. Our findings reveal that although women, on average, receive larger loans from family and close friends than their male counterparts, they must demonstrate a high personal investment in their business and number of employees in order to obtain these larger loans. Thus, while family and close friends are willing to financially support women entrepreneurs, the women must prove their business' quality and commitment to their business to obtain larger loan amounts. Conversely, men entrepreneurs do not appear to be held to such a standard. As such, even family and close friends show some gender bias against women entrepreneurs when granting loans.

\section{Introduction}

It has long been recognized that women entrepreneurs struggle to obtain bank financing for their business (Brush, Carter, Greene, Gatewood \& Hart, 2001; Buttner \& Rosen, 1988; Jennings \& Brush, 2013). Although some studies have suggested little difference in women and men entrepreneurs' access to bank financing (Arenius \& Autio, 2006; Becker-Blease \& Sohl, 2007; Carter, Shaw, Lam \& Wilson, 2007; Wilson, Carter, Togg, Shaw \& Lam, 2007), more fine-grained research has revealed more subtle and 'second order' gender discrimination (Eddleston, Ladge, Mitteness \& Balachandra, 2016). For example, women entrepreneurs are charged higher interest rates (Fraser, 2005; Wu \& Chua, 2012) and receive smaller loan amounts than their male counterparts (Eddleston et al., 2016; Verheul \& Thurik, 2001; Zimmerman, Treichel \& Scott, 2006). Further, research recently discovered that women entrepreneurs are held to a higher standard, which results in them receiving significantly lower bank

loan amounts than men (Eddleston et al., 2016). For example, a high number of employees and strong firm performance contributed much more positively to men's than women's bank loan amounts. Young businesses owned by men also received significantly greater bank loan amounts than those owned by women. Due to problems in gaining legitimacy and receiving fair treatment by banks, women entrepreneurs may therefore turn to family and close friends for financing (Arenius \& Autio, 2006; Murphy, Kickul, Barbosa \& Titus, 2007; Wilson et al., 2007).

However, whether women have an easier time acquiring loans from family and close friends is not known. Women entrepreneurs may have an advantage since research has shown that in comparison to men, they tend to be better able to capitalize on family-related sources of support like affective enrichment (i.e. positive emotions transferred from the family to business domain) and family members' interpersonal support for the business (i.e. offering feedback, contributing free labor) (Powell \& Eddleston, 2013). The synergies women create and maintain between their family and business may therefore lead to greater loan amounts from family and close friends. Yet, research also suggests that family and close friends appear to more closely scrutinize the legitimacy of women entrepreneurs (Murphy et al., 2007). Since gender roles are deeply embedded within the family domain and close social circles (Eagly, 1987; Ridgeway \& Correll, 2004), the potential of women-owned businesses may not be fully appreciated by family and close friends. Gender role congruity theory explains that due to perceived incongruity between traditional gender norms and entrepreneurship expectations, women entrepreneurs are perceived less favorably than their male counterparts (Eddleston et al., 2016). It is therefore necessary to explore the loan amounts given by family and close friends to women versus men entrepreneurs and if they hold women to a higher
Copyright @ 2018 The Authors. Entrepreneur \& Innovation Exchange is published at EIX.org. This is an open access article under the terms of the Creative Commons Attribution-NoDerivs License, which permits use and distribution in any medium, provided the original work is properly cited and no modifications or adaptations are made. View EIX.org Authorship Terms at https://eix.org/terms
FamilyBusiness 
standard.

Accordingly, this study seeks to shed light on the loan amounts that women and men entrepreneurs receive from family and close friends and if there are differences in their loan amounts due to gender biases. Drawing from research on the work-family interface of entrepreneurs, it is first argued that due to synergies between work and family for women (Eddleston \& Powell, 2012; Powell \& Eddleston, 2013), they will tend to receive greater loan amounts from family and close friends than men. This research also suggests that women may be more likely to rely on informal support from family and close friends because they are less likely to receive resources from formal sources like banks (Powell \& Eddleston, 2013), which we explore. Additionally, similar to the study by Eddleston et al. (2016) on bank loans, we examine if family and close friends hold women entrepreneurs to a higher standard than men when granting loans. Our results contribute to the literature on women's entrepreneurship and the financing of small businesses by demonstrating that while women, in general, receive higher loan amounts from family and close friends than do men, they are held to a higher standard. That is, women need to demonstrate greater personal investment in their business and a higher number of employees in order to receive loans from family and close friends. We also discover that family and close friends do not discern between male entrepreneurs' with high versus low personal investment or number of employees. Rather, family and close friends appear to give male entrepreneurs loans regardless of their apparent commitment to the business or number of employees. As such, while some may have hoped that gender congruity theory does not apply among family and close friends, the results of our study suggest otherwise. Furthermore, the results uncover some unexpected gender-based advantages that women and men entrepreneurs may be able to use to their advantage when seeking loans from family and close friends.

\section{The Female Advantage}

Because women are better able to create synergies between work and family than men, they are more effective at utilizing resources acquired from their family for the benefit of their business (Powell \& Eddleston, 2013). Since gender stereotypes dictate that women should emphasize family and close relationships (Wood \& Eagly, 2010), they may be more comfortable seeking financing from family and close friends than men.
Gender stereotypes that promote the need for family and close friends to care for, protect and nurture women (Spence \& Helmreich, 1979; Warner \& Steele, 1999) should also encourage family and close friends to be more willing to provide loans to women than to men entrepreneurs.

In contrast, since the male stereotype stresses the importance of independence while the female stereotype promotes dependence (Eddleston \& Powell, 2008; Heilman, 2001; Spence \& Helmreich, 1979), family and close friends may feel more compelled to provide women entrepreneurs with business loans. In other words, gender norms that make it acceptable for women to rely on family and friends for support should increase their ability to acquire loans from family and close friends, in comparison to men who are expected to display self-reliance and independence. Further, due to gender biases displayed by banks, women entrepreneurs may need to rely more on loans from family and close friends than do their male counterparts who experience less obstacles when seeking bank financing (Eddleston et al., 2016). These arguments lead to the following hypothesis:

Hypothesis 1: Women entrepreneurs receive greater loan amounts from family and close friends than do men entrepreneurs.

Hypothesis 1 predicts that family and close friends provide larger loan amounts to women than men entrepreneurs because of gender stereotypes that promote care and nurturing of women and also support women's dependence on family and close friends. However, when considering how women are rewarded for their commitment to the business and the business's display of quality, gender role congruity theory suggests a different result.

\section{Gender Role Congruity Theory}

Women have long struggled to raise capital to support and grow their new ventures (Jennings \& Brush, 2013). For example, despite similar efforts to seek a variety of financing, women entrepreneurs experience greater difficulty obtaining funding relative to their male counterparts (Eddleston et al., 2016; Verheul \& Thurik, 2000). Research has uncovered discriminatory practices by bank loan officers who evaluated women entrepreneurs much lower than men entrepreneurs on key traits associated with successful entrepreneurship (Buttner \& Rosen, 1988; Eddleston et al., 2016). Others 
have also pointed to overt discrimination practices to explain why women and men vary in acquiring funding for their business (Riding \& Swift, 1990; Fay \& Williams, 1993).

Recently, Eddleston and colleagues (2016) extended gender role congruity theory to the study of entrepreneurial attainment of bank loans by proposing that the male model of entrepreneurship creates a hurdle for women because their gender role conflicts with the male model of entrepreneurship. Gender role congruity theory maintains that women are perceived less favorably than men in positions of leadership due to perceived incongruity between traditional gender norms and leadership role expectations (Eagly \& Karau, 2002). The combination of a stereotyped group member (i.e. a woman) and an incongruent social role (i.e. entrepreneur) creates an inconsistency in the perceivers' mind, which thereby damages how the group member is viewed in that role. Gender role congruity theory therefore suggests that when capital providers assess the characteristics of an entrepreneur's firm, that implicit gender expectations influence the evaluation of the firm based on expectations and assumptions typically ascribed to entrepreneurship. As a result, women and men are evaluated differently for possessing similar entrepreneurial characteristics since the male gender role aligns with what it means to be an entrepreneur, and the female gender role does not.

\section{The Female Disadvantage: Female Gender Incongruity with Entrepreneurship}

To align with Eddleston et al.'s (2016) study comparing how women and men entrepreneurs are rewarded for the quality of their business and personal inputs, we focus on several common characteristics that previous research has linked to new venture success and the procurement of bank financing: age of the firm (Haines, Orser \& Riding, 1999), size of the firm (Aldrich \& Auster, 1986; Haines et al. 1999), firm performance (Wiklund \& Shepherd, 2003; Haines et al., 1999), and the entrepreneur's investment of time and money in the business (Gimeno, Folta, Cooper \& Woo, 1997; Wilson et al., 2007). Drawing from signaling theory, Eddleston et al. (2016) argued that these characteristics act as a means to communicate (i.e. signal) the inherent quality of the venture and the entrepreneur's commitment, thereby increasing the amount of capital raised. While the business's characteristics signal legitimacy to overcome liabilities of newness and smallness, those associated with the entrepreneur's commitment signal their dedication to the business. Results from their study indicated that number of employees, firm performance and number of hours dedicated to the business significantly predicted the bank loan amount acquired by entrepreneurs, although number of hours was only marginally significant. Additionally, and most germane to this study, they found that banks tend to reward women less than men for these signals of business quality and entrepreneurial commitment.

More specifically, Eddleston et al. (2016) found that as the number of employees and firm performance increased, men entrepreneurs received significantly greater bank loans than did women entrepreneurs. The men with a young new venture also received significantly greater loan amounts than did women with a young new venture, suggesting that the "liability of newness" is much more of a burden for women when seeking bank loans. As such, their study demonstrated that business characteristics are evaluated differently by banks based on the gender of the entrepreneur and that women entrepreneurs are held to a higher standard than their male counterparts. Extending this logic to financing from family and close friends therefore suggests that women entrepreneurs may be under-rewarded for the display of business quality and commitment to their business, in comparison to men entrepreneurs.

Gender stereotypes lead capital providers to view women's businesses as a hobby, part-time, or an extension of their home-maker role, thus leading them to view their businesses as less attractive investments than those owned by men (Arenius \& Autio, 2006; Loscocco \& Smith-Hunter, 2004). Regardless of the actual performance or the entrepreneur's commitment to the business, gender stereotypes cause women entrepreneurs to be perceived less favorably than men entrepreneurs (Jennings \& Brush, 2013; Murphy et al., 2007). Indeed, research suggest that family and close friends only offer support to women entrepreneurs when they are perceived as highly credible (Murphy et al., 2007). As a result, women entrepreneurs may have greater difficulties communicating the quality of their business and their entrepreneurial commitment to family and close friends when seeking loans. Further, since beliefs regarding gender stereotypes tend to be particularly strong within the family domain and close social circles (Eagly, 1987), the potential of women- 
owned businesses may not be fully appreciated by family and close friends. This is in line with Heilman's (1983) research on lack-of-fit that found that when an individual's attributes are perceived as not fitting a work role, that individual is regarded as less likely to succeed and meet performance expectations. In accordance with gender role congruity theory and the male stereotype of entrepreneurship, women entrepreneurs are therefore expected to receive smaller loans from family and close friends than men entrepreneurs for the display of business quality and commitment to their business.

Hypothesis 2: Being a woman entrepreneur moderates the relationship between (a) number of employees, (b) age of business, (c) hours devoted to business, (d) firm performance, and (e) personal investment in the business such that men will be rewarded greater loan amounts from family and close friends than women for the display of business quality and commitment to the business.

\section{METHOD \\ Data Source}

Because the purpose of our study was to examine differences between the loan amounts obtained by women and men entrepreneurs, data was sought from approximately equal numbers of men and women who had founded their own businesses. However, since the majority of entrepreneurs are male (Kepler \& Shane, 2007), we utilized the Center for Women and Enterprise (CWE) to assist in the gathering of survey data from female entrepreneurs. CWE is a national organization that is dedicated to helping women start and grow their own business. Although not all participants in CWE programs are female, only about $20-30 \%$ of their participants are male. Therefore, we also surveyed entrepreneurs who were associated with a universitybased entrepreneurship program located in the same city as CWE. The university population was expected to be predominantly male.

We mailed surveys to 300 entrepreneurs in the university population and 990 entrepreneurs in the CWE population. For the university population, 90 (30\%) usable surveys were returned, and for the CWE population, 163 (16\%) usable surveys were returned.

In order to determine if data from the two populations could be combined to test the hypotheses, univariate analysis of variance tests were conducted controlling for gender. When controlling for gender, there were no significant differences between entrepreneurs sampled from the CWE or university populations and their businesses for the following variables: age (46.18), race/ethnicity (83\% Caucasian, 10\% African American, 4\% Asian American, 2\% Hispanic, 2\% other), marital status (61\% married, 24\% single, $12 \%$ divorced, $2 \%$ separated, $1 \%$ widowed), number of children $(M=.66)$, years in business $(M=10.19$ years $)$, employees $(M=7.68)$ and sales $(M=\$ 725,000)$. Therefore, given the lack of differences between the CWE and university samples when entrepreneur gender was controlled, data from the two populations were combined to test our hypotheses. However, due to missing data regarding whether loans were obtained from family and close friends, the sample used to test the hypotheses consisted of 162 business owners who also managed their business.

\section{Measures \\ Dependent Variables}

The amount of financing recently procured from family and close friends was assessed by asking respondents the cumulative amount of loans received within the last couple of years (Berger \& Udell, 2003). In our sample, $28 \%$ of women and $31 \%$ of men reported recently receiving a loan from family and close friends. Of the women who received a loan from family and close friends, $42 \%$ had also previously received a bank loan. Of the men who received a loan from family and close friends, $46 \%$ had also previously received a bank loan.

\section{Independent Variables}

Number of employees was measured by asking respondents how many people are employed by the firm full-time. Age of business was assessed by asking respondents to report how many years their business has been in operation. Hours devoted to the business was captured by asking respondents to report the hours they devote to the business in a typical work week. Personal investment in the business was captured by asking respondents how much start-up capital they personally invested during the first year of the business. Finally, firm performance was assessed with multiple indicators of business success thereby capturing richer information than single indicators of performance (Birley \& Westhead, 1990; Wiklund, Patzelt \& Shepherd, 2009). In line with recent calls for entrepreneurship performance measures to consider how small 
businesses compare to competing businesses in their industry (Wiklund et al., 2009), respondents were asked to rate their business's performance on a 7-point scale ( 1 = much worse than competitors, $4=$ about the same as competitors, $7=$ much better than competitors) on growth in sales, growth in market share, growth in number of employees, growth in profitability, ability to fund growth from profits, and profit margin on sales. These six items were averaged to yield a firm performance score with higher values indicating stronger performance $(a=.95)$. A similar measure of entrepreneurial performance has been used by Ling \& Kellermanns (2010) and Powell \& Eddleston (2013). Further, Ling \& Kellermanns (2010) showed that selfreported measures of business performance compared to competitors demonstrate convergent validity with actual sales growth for privately-held businesses.

\section{Moderator Variable}

Whether the entrepreneur was male or female was coded as $0=$ man and $1=$ woman.

\section{Control Variables}

We controlled for four characteristics of entrepreneurs and their firms that may have influenced the relationships examined. Because entrepreneurs' family structure and human capital may influence their business and personal outcomes (Baron, 2002; Jennings \& McDougald, 2007), marital status (married/unmarried), number of children, and education (highest level attained) were controlled. Because the type of industry in which a firm operates tends to vary based on the gender of the owner (Anna, Chandler, Jansen \& Mero, 1999) and may influence financing opportunities, we controlled for whether or not the firm operated in a traditional industry for female entrepreneurs.

\section{Results}

Table 1 reports means, standard deviations, and correlations for the unstandardized variables. Table 2 reports the results of the moderated hierarchical ordinary least squares regression analyses that were conducted to test the hypotheses. In order to facilitate the interpretation of the moderation results, the significant interaction effects were plotted (Aiken \& West, 1991; Cohen, Cohen, West, \& Aiken, 2003).

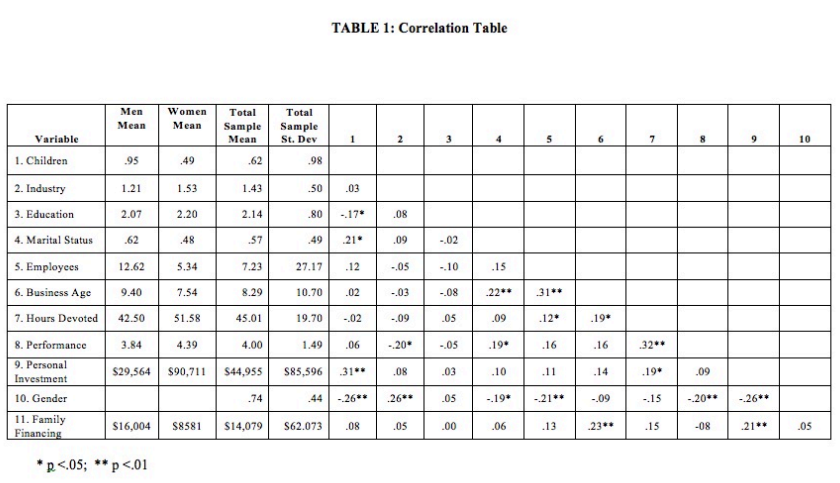

TABLE 2: Multiple Regression Analysis:

Dependent Variable: Financing from Family and Close Friends

\begin{tabular}{|c|c|c|c|}
\hline Variables & Model 1 & Model 2 & Model 3 \\
\hline \multicolumn{4}{|l|}{ Step 1: Controls \& Main Effects } \\
\hline \multicolumn{4}{|l|}{ Controls: } \\
\hline Industry & -.08 & -.13 & -.10 \\
\hline Education & .00 & .01 & -.01 \\
\hline Marital Status & .05 & .08 & .07 \\
\hline Number of Children & .02 & .04 & .07 \\
\hline \multicolumn{4}{|l|}{ Main Effects: } \\
\hline Number of Employees & .05 & .08 & .01 \\
\hline Age of Business & $.19^{*}$ & $.18^{*}$ & .07 \\
\hline Hours Devoted to Business & .12 & .13 & .15 \\
\hline Firm Performance & $-.19 *$ & $-.18^{*}$ & -.04 \\
\hline Personal Investment & $.17^{*}$ & $.21^{*}$ & .06 \\
\hline \multicolumn{4}{|l|}{ Step 2: Moderator } \\
\hline Gender & & $.19^{*}$ & $.24^{* *}$ \\
\hline \multicolumn{4}{|l|}{ Step 3: Interaction Effects } \\
\hline Gender * Number of Employees & & & $.19^{*}$ \\
\hline Gender * Age of Business & & & .04 \\
\hline Gender * Hours Devoted to Business & & & -.10 \\
\hline Gender * Firm Performance & & & -.13 \\
\hline Gender * Personal Investment & & & $.28 * *$ \\
\hline $\mathrm{R}^{2}$ & .13 & .16 & .23 \\
\hline Adjusted $\mathrm{R}^{2}$ & .08 & .10 & .15 \\
\hline$\Delta \mathrm{R}^{2}$ & & $.03^{*}$ & $.08^{* *}$ \\
\hline F & $2.50 * *$ & $2.80^{* *}$ & $2.93 * * *$ \\
\hline
\end{tabular}

$\mathrm{N}=162 .{ }^{*} \mathrm{p}<.05 ;{ }^{* *} \mathrm{p}<.01 ;{ }^{* * *} \mathrm{p}<.001$

a Regression coefficients are reported as betas.

Regarding main effects, while no controls were significant, business age $(\beta=.19, p<.05)$ and personal investment $(\beta=.17, p<.05)$ in the business were found to be significantly positively related to the amount of funding received from family and close friends, and firm performance $(\beta=-.19, p<.05)$ was found to be significantly negatively related to the amount of funding received from family and close friends.

Turning to the hypotheses, gender was shown to be positively related to the amount of funding received, thus showing that family and close friends invest more money in women than men-owned businesses $(\beta=.19$, $\mathrm{p}<.05)$, thus providing support for Hypothesis 1. In 
regards to the moderation results, two of the five hypothesized interaction effects were found to predict the amount of funding received from family and close friends. The addition of the interaction effects significantly contributed to the model $(\Delta \mathrm{R} 2=.08$, $p<.01)$. The significant interaction effects were plotted in Figures 1 and 2 to facilitate their interpretation. Higher personal investment $(\beta=.28, p<.01)$ and number of employees $(\beta=.19, p<.05$ ) were found to contribute significantly more to the amount of funds received from family and close friends by women than men entrepreneurs. Further, our results revealed that whether a man had high or low personal investment in his business or had a high or low number of employees did not predict the loan amount he received from family and close friends. Thus, while the loan amounts women received from family and close friends depended on their personal investment in their business and number of employees, men appeared to receive moderate loans from family and close friends regardless of the quality of their business or entrepreneurial commitment.

FIGURE 1

Moderating Effect of Gender on Relationship between Personal Investment and Family \& Close Friend Financing

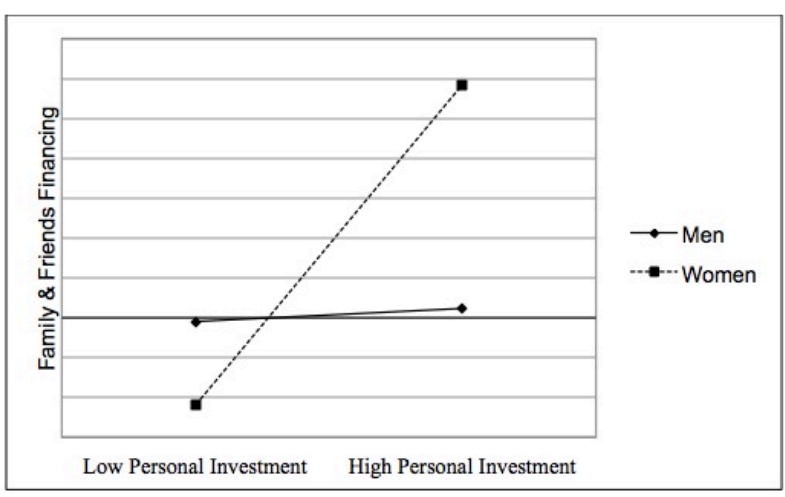

FIGURE 2

Moderating Effect of Gender on Relationship between Number of Employees and Family \& Close Friend Financing

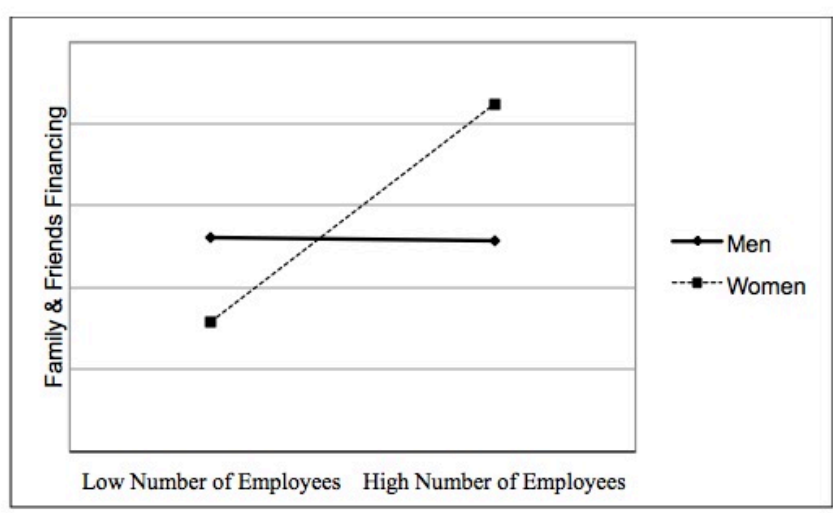

\section{Discussion}

Building on research that has investigated differences in women and men entrepreneurs' access to bank financing (i.e. Arenius \& Autio, 2006; Orser, Riding \& Manley, 2006; Wilson et al., 2007) and their bank loan amounts (Eddleston et al., 2016; Verheul \& Thurik, 2001; Zimmerman et al., 2006), we explored if family and close friends also show gender biases when granting loans. Our study revealed both advantages and disadvantages that women (and men) entrepreneurs experience when seeking loans from family and close friends.

More specifically, our study showed that women entrepreneurs, on average, receive larger loan amounts from family and close friends than do men entrepreneurs. As such, women appear to have an advantage when seeking loans for their business from family and close friends; which is in stark contrast to research on bank loans, angel investors and venture capital. This finding reinforces the traditional stereotype that women entrepreneurs tend to rely on personal relationships (Fletcher, 2001). It also lends some support to the argument that women rely more on family and friends for funding because they assume they won't be able to obtain financing from banks (Arenius \& Autio, 2006; Murphy et al., 2007).

Indeed, women's reliance on family and close friends for financing could be due to gender biases they experience when seeking financing from banks (Eddleston et al., 2016). In looking closer at our data, we found that although men only received $\$ 8581$, on average, from family and close friends, on average they 
obtained $\$ 681,917$ in bank loans. In comparison, women received $\$ 16,004$, on average, from family and close friends, but only obtained $\$ 39,218$ in bank loans, on average. Further, although a similar proportion of women and men in our study received loans from family and close friends (28\% versus $31 \%$, respectively), $43 \%$ of men but only $25 \%$ of women received loans from banks. Taken together, it therefore appears that family and close friends help compensate for gender biases shown by banks towards women entrepreneurs. As such, this study provides further evidence on how the family (and close friends) enriches the businesses of women entrepreneurs.

Turning to our findings regarding the moderation effect of gender, loan amounts from family and close friends granted to female entrepreneurs were significantly positively influenced by their number of employees and personal investment in the business. Our findings support Murphy et al's (2007) argument that women entrepreneurs must establish legitimacy with informal contacts, like family and friends, in order to receive financing from them. However, our findings also extend their study by highlighting how women gain significantly more funds than men from family and friends when they have a high number of employees or personal investment in the business. Yet, as our results indicate, this hurdle does not exist for men. Men's loan amounts from family and friends were not influenced by their number of employees or personal investment in the business. Thus, it appears that the male stereotype of entrepreneurship (Ahl, 2006; Bruni, Gherardi \& Poggio, 2004) benefits men when seeking loans from family and friends and that family and friends are more discerning when offering loans to women entrepreneurs. But, to the advantage of women, our results show that family and friends are more generous in their loan amounts when women own businesses with a high number of employees or have a high personal investment in the business.

Finally, regarding main effects, our study showed that family and close friends grant entrepreneurs larger loans when their business is older and they have made greater personal investments in the business. Surprisingly, the results also showed that family and close friends grant larger loans to entrepreneurs with low firm performance. This suggests that while family and close friends reward entrepreneurs who demonstrate strong commitment to their business, as demonstrated by longevity and personal investment, they are also altruistic in making loan decisions since they are willing to invest more money in those firms that appear to be suffering from performance problems.

Accordingly, these results have important implications for entrepreneurship research and theory. Our study adds to the entrepreneurship literature by demonstrating that business characteristics are often evaluated based on the gender of the entrepreneur, even by family and close friends. As such, our research highlights the gendered context of entrepreneurship financing by showing that although women, on average, receive larger loan amounts than men from family and close friends, they must demonstrate high personal investment in their business and have a high number of employees in order to gain those larger loans. In contrast, while men may be disadvantaged in regards to loan amounts from family and close friends, those who have low personal investment and number of employees still receive similar loan amounts as men with high personal investment and number of employees. Thus, men appear to obtain moderate loan amounts from family and close friends regardless of the quality of their business or entrepreneurial commitment while women's business loan amounts significantly depend on their personal investment in the business and number of employees. As such, family and friends appear to be much more discerning in offering business loans to women versus men. In this way, women appear to be at an advantage in that they can obtain larger loan amounts from family and close friends, but also at a disadvantage since only those with high personal investment in the business and number of employees will receive these larger loans.

Further, our results suggest that female entrepreneurs may turn to family and friends for financing in order to offset gender-based discrimination from banks that limit their loan amounts. Future research should explore how female and male entrepreneurs secure different sources of financing over time and how the successful procurement of a loan contributes to additional financing success. For example, considering the stage of the venture's development, do different factors contribute to women's and men's ability to raise capital, and from what sources? When does gender stop making a difference in how women-owned businesses are funded? It would also be interesting to investigate how the loan amounts sought from women versus men influence the loan amounts they receive. Although we did not gather information on the loan amounts 
requested from family and friends, we did collect data on the amount of financing that the female and male entrepreneurs currently desire. While women, on average, would like to raise $\$ 230,797$ in financing to grow their business to a desired level, men, on average, would like to raise $\$ 554,000$. Given this discrepancy, future research should investigate why differences exist in the funds sought by female and male entrepreneurs and how this effects their businesses' growth over time.

This study contributes to theory in two specific ways. First, by extending gender role congruity theory to entrepreneurial finance by family and close friends, we demonstrated that signals of business quality and commitment are interpreted differently depending on the gender of the entrepreneur. Second, our study shows the applicability of gender role congruity theory to entrepreneurship by suggesting that gender stereotypes influence the degree to which women and men entrepreneurs are rewarded for their achievements, even by family and close friends. More research is needed to explore why family and close friends appear to discern between women entrepreneurs with high versus low personal investment in their business and number of employees, while they do not discern between men entrepreneurs. It is also necessary to investigate if women receive more financing from family and friends than men because they receive significantly smaller loans from banks.

\section{Limitations}

Before concluding, a few limitations of our study should be noted. First, because this study was cross-sectional, cause-and-effect relationships should not be inferred; analyses that were conducted cannot prove causation but merely support a set of hypothesized paths. Second, because the variables were measured at the same time from the same source, common method variance cannot be fully ruled out (Podsakoff \& Organ, 1986). However, the presence of common method bias does not necessarily affect results or conclusions (Spector, 2006). Third, because our sample consisted of entrepreneurs who were affiliated with entrepreneurship centers (i.e. participated in programs and/or signed up for their mailing list), there could be a systemic bias in our sample towards entrepreneurs who are willing to seek financial assistance. In the future, scholars may wish to consider the financing of small businesses among different sample settings and contexts. Finally, comparable to other survey-based studies of entrepreneurs (e.g., Anna et al., 1999; DeTienne \&
Chandler, 2007; Eddleston \& Powell, 2008), our study suffered from a low response rate, and respondents may have represented a self-selecting minority that were not representative of the majority.

In conclusion, our study reveals both advantages and disadvantages that women entrepreneurs experience when obtaining loans from family and close friends. Although women, on average, receive larger loans from family and close friends than their male counterparts, they must demonstrate a high personal investment in their business and number of employees in order to obtain these larger loans. Thus, while family and close friends are willing to financially support women entrepreneurs, the women must prove their business' quality and commitment to their business to obtain larger loan amounts. Conversely, men entrepreneurs do not appear to be held to such a standard. As such, even family and close friends show some gender bias against women entrepreneurs.

\section{References}

Ahl, H. (2006). Why research on women entrepreneurs needs new directions. Entrepreneurship Theory and Practice, 30(5), 595-621.

Aiken, L.S. \& West, S.G. (1991). Multiple regression: Testing an interpreting interactions. Newbury Park, CA: Sage.

Aldrich, H.A. \& Auster, E. (1986). Even dwarfs started small: Liabilities of size and age and their strategic implications. In B.M. Staw \& L.L. Cummings (Eds.), Research in organizational behavior (Vol. 8, pp. 165-198). Greenwich, CT: JAI Press.

Anna, A.L., Chandler, G.N., Jansen, E., \& Mero, N.P. (2000). Women business owners in traditional and nontraditional industries. Journal of Business Venturing, 15(3), 279-303.

Arenius, P. \& Autio, E. (2006). Financing of small businesses: Are Mars and Venus more alike than different? Venture Capital, 8(2), 93-107.

Baron, R.A. (2002). OB and entrepreneurship: The reciprocal benefits of closer links. Research in Organizational Behavior, 24, 225-269.

Becker-Blease, J.R. \& Sohl, J.E. (2007). Do womenowned businesses have equal access to angel capital? Journal of Business Venturing, 22(4), 503-521. 
Berger, A.N. \& Udell, G.F. (2003). The economics of small business finance: The roles of private equity and debt markets in the financial growth cycle. Journal of Banking and Finance, 22, 613-673.

Birley, S. \& Westhead, P. (1990). Growth and performance contrasts between "types" of small firms. Strategic Management Journal, 11(7), 535-557.

Bruni, A., Gherardi, S., \& Poggio, B. (2004). Entrepreneur mentality, gender and the study of women entrepreneurs. Journal of Organizational Change Management, 17(3), 256-268.

Brush, C., Carter, N., Greene, P., Gatewood, E., \& Hart, M. (2001). An investigation of women-led firms and venture capital investment. Report to the US SBA Office of Advocacy/National Women's Business Council. Duxbury, MA: C. B. Associates.

Buttner, E.H. \& Rosen, B. (1988). Funding new business ventures; are decision makers biased against women business owners? Journal of Business Venturing, 4, 249-261.

Carter, S., Shaw, E., Lam, W., \& Wilson, F. (2007). Gender, entrepreneurship, and bank lending: The criteria and processes used by bank loan officers in assessing applications. Entrepreneurship Theory and Practice, 31, 427-444.

Cohen, J., Cohen, P., West, S. G., \& Aiken, L. S. (2003). Applied multiple correlation/regression analysis for the behavioral sciences. UK: Taylor \& Francis.

DeTienne, D.R. \& Chandler, G.N. (2007). The role of gender in opportunity identification. Entrepreneurship Theory and Practice, 31(3), 365-386.

Eagly, A. (1987). Sex differences in social behavior: A social-role interpretation. Hillsdale, $\mathrm{NJ}$ : Erlbaum.

Eagly, A.H. \& Karau, S.J. (2002). Role congruity theory of prejudice toward female leaders. Psychological Review, 109(3), 573-598.

Eddleston, K.A., Ladge, J., Mitteness, C. \& Balachandra, L. (2016). Do you see what I see? Signaling effects of gender and firm characteristics on financing entrepreneurial ventures. Entrepreneurship Theory and Practice, 40(3), 489-514.
Eddleston, K.A. \& Powell, G.N. (2008). The role of gender identity in explaining sex differences in business owners' career satisfier preferences. Journal of Business Venturing, 23, 244-256.

Eddleston, K.A. \& Powell, G.N. (2012). Nurturing entrepreneurs' work-family balance: A gendered perspective. Entrepreneurship Theory and Practice, 36, 513-541.

Fay, M. \& Williams, L. (1993). Gender bias and the availability of business loans. Journal of Business Venturing, 8, 363-377.

Fraser, S. (2005). Finance for small and medium sized enterprises: A report on the 2004 UK Survey of SME Finances. Warwick Business School, University of Warwick, Coventry.

Gimeno, J., Folta, T. B., Cooper, A. C., \& Woo, C. Y. (1997). Survival of the fittest? Entrepreneurial human capital and the persistence of underperforming firms. Administrative Science Quarterly, 750-783.

Haines, G.H., Jr, Orser, B.J., \& Riding, A.L. (1999). Myths and realities: An empirical study of banks and the gender of small business clients. Canadian Journal of Administrative Sciences, 16(4), 291-307.

Heilman, M. E. (2001). Description and prescription: How gender stereotypes prevent women's ascent up the organizational ladder. Journal of Social Issues, 57(4), 657-674.

Jennings, J.E. \& Brush, C.G. (2013). Research on women entrepreneurs: Challenges to (and from) the broader entrepreneurship literature? Academy of Management Annals, 7(1), 663-715.

Jennings, J.E. \& McDougald, M.S. (2007). Work-family interface experiences and coping strategies: Implications for entrepreneurship research and practice. Academy of Management Review, 32, 747-760.

Kepler, E. \& Shane, S. (2007). Are male and female entrepreneurs really that different? Washington, DC: U.S. Small Business Administration, Office of Advocacy. Available at http://www.sba.gov, accessed 12 October 2007.

Ling, Y. \& Kellermanns, F.W. (2010). The effects of family firm specific sources of TMT diversity: The 
moderating role of information exchange frequency. Journal of Management Studies, 47(2), 322-344.

Loscocco, K. \& Smith-Hunter, A. (2004). Women homebased business owners: Insights from comparative analyses. Women in Management Review, 19(3), 164-173.

Murphy, P.J., Kickul, J., Barbosa, S.D., \& Titus, L. (2007). Expert capital and perceived legitimacy: Femalerun entrepreneurial venture signaling and performance. International Journal of Entrepreneurship \& Innovation, 8(2), 127-138.

Orser, B.J., Riding, A.L., \& Manley, K. (2006).Women entrepreneurs and financial capital. Entrepreneurship Theory and Practice, 14(3), 643-665.

Podsakoff, P.M. \& Organ, D.W. (1986). Self-reports in organizational research: Problems and perspectives. Journal of Management, 12, 531-544.

Powell, G.N. \& Eddleston, K.A. (2013). Linking family-tobusiness enrichment and support to entrepreneurial success: Do female and male entrepreneurs experience different outcomes? Journal of Business Venturing, 28(2), 261-280.

Ridgeway, C.L. \& Correll, S.J. (2004). Unpacking the gender system a theoretical perspective on gender beliefs and social relations. Gender \& Society, 18(4), 510-531.

Riding, A.L. \& Swift, C.S. (1990). Women business owners and terms of credit: Some empirical findings of the Canadian experience. Journal of Business Venturing, 5, 327-340.

Spector, P.E. (2006). Method variance in organizational research: Truth or urban legend? Organizational Research Methods, 9, 221-232.

Spence, J. T., \& Helmreich, R. L. (1979). Masculinity and femininity: Their psychological dimensions, correlates, and antecedents. University of Texas Press.

Verheul, I. \& Thurik, R. (2001). Start-up capital: Does gender matter? Small Business Economics, 16, 329-345.

Warner, R. L., \& Steel, B. S. (1999). Child rearing as a mechanism for social change: The relationship of child gender to parents' commitment to gender equity. Gender \& Society, 13(4), 503-517.

Wiklund, J., Patzelt, H., \& Shepherd, D.A. (2009). Building an integrative model of small business growth. Small Business Economics, 32, 351-374.

Wiklund, J. \& Shepherd, D. (2003). Knowledge-based resources, entrepreneurial orientation, and the performance of small and medium-sized businesses. Strategic Management Journal, 24(13), 1307-1314.

Wilson, F., Carter, S., Tagg, S., Shaw, E., \& Lam, W. (2007). Bank loan officers' perceptions of business owners: The role of gender. British Journal of Management, 18, 154-171.

Wood,W. \& Eagly, A.H. (2010). Gender. In S.T. Fiske, D.T. Gilbert, \& G. Lindzey (Eds.), Handbook of social psychology (5th ed., Vol. 1, pp. 629-667). New York: Oxford University Press.

Wu, Z. \& Chua, J.H. (2012). Second-order gender effects: The case of U.S. small business borrowing cost. Entrepreneurship Theory and Practice, 36, 443-463.

Zimmerman, M.A., Treichel, M., \& Scott, J. (2006). Women-owned businesses and access to bank credit: A time series perspective (evidence from three surveys since 1987). Venture Capital, 8(1), 51-67. 